THE POLITICS OF CULTURE IN

THE SHADOW OF CAPITAL

POST-CONTEMPORARY INTERVENTIONS

Series Editors: Stanley Fish and Fredric Jameson 

The

POLITICS

of CULTURE

in the SHADOW

\section{of CAPITAL}

Edited by LISA LOWE

and DAVID LLOYD

Duke University Press

Durham \& London 
(C) 1997 Duke University Press

All rights reserved Printed in the United

States of America on acid-free paper $\infty$

Typeset in Sabon 3 with Scala Sans display

by Keystone Typesetting, Inc.

Library of Congress Cataloging-in-Publication

Data appear on the last printed page of

this book. 